\title{
A REPRESENTATIVE OF THE MAINLY ABYSSAL FAMILY PARDALISCIDAE (CRUSTACEA, AMPHIPODA) IN CAVE WATERS OF THE CAICOS ISLANDS
}

\author{
JAN H. STOCK \& JAN J. VERMEULEN \\ Institute of Taxonomic Zoology, University of Amsterdam, \\ P.O. Box 20125, 1000 HC Amsterdam, The Netherlands
}

\begin{abstract}
A new genus and species of Amphipoda is described from cave waters on Providenciales (Caicos Islands) as Spelaeonicippe provo. Another species belonging to the same new genus is known from a cave on Lanzarote (Canary Islands). The genus belongs to the Pardaliscidae, a predominantly bathyal/ abyssal family. A possible evolutionary scenario for both species is discussed.
\end{abstract}

\section{RESUME}

On décrit un genre et espèce nouveaux d'Amphipodes des eaux d'une grotte de Providenciales (Iles Caicos), sous le nom de Spelaeonicippe provo. Une autre espèce appartenant au même genre est connue d'une grotte de Lanzarote (Iles Canaries). Le genre appartient aux Pardaliscidae, famille connue surtout des étages bathyal et abyssal. On présente un scénario évolutif plausible pour ces deux espèces.

\section{INTRODUCTION}

During a survey of the groundwater fauna of the Bahamas and the adjoining islands in the West Indies, a sample of Amphipoda was taken in a so-called "water hole" on Providenciales, an island in the western part of the Caicos group, to the north of Haiti. The "water hole" in question is an oblique fissure in the calcareous rocks, in direct contact with the underlying water table. This particular "water hole" may be classified as a "marginal cave" (sensu Riedl \& Ozretič, 1969) or anchihaline habitat (sensu Holthuis, 1973), since the high chlorinity of its waters $(11.1 \%$ oo $)$ points to extensive subterranean connections with

*) Report no. 15 has been published in Bijdr. Dierk., 51 (2): 375.387 (1981). the sea (the nearest sea coast is some $11 / 2 \mathrm{~km}$ from the cave entrance). The accessible part of the water hole is in semidarkness.

The Amphipoda from this cave have been observed free-swimming ("pelagic") in the water. They are unpigmented, with a pink intestine, and devoid of eye pigment. The accompanying fauna is relatively poor, consisting of several species of Gastropoda. Dr. H. E. Coomans (Institute of Taxonomic Zoology, University of Amsterdam) has been kind enough to examine these mollusks and he informs us (in litt.) that seven species are represented. Dead shells of Echininus nodulosus (Pfeiffer, 1839), Truncatella caribaeensis (Reeve, 1842 ), and Melampus (Microtralia) sp. (possibly M. minusculus) were present, together with live and dead specimens of Lyrodes sp. Of these, $E$. nodulosus and $T$. caribaeensis are living in the marine fringe of the supralittoral of the coast; Lyrodes lives in pools and springs, near the sea; Melampus is an inhabitant of brackish waters. All are superficial species, and all indicate a certain relation to the marine environment. In addition, the cave yielded a number of terrestrial snails, all no doubt washed in from the surface, viz., Bothriopupa sp., Gastrocopta sp., and members of the family Chrondropomidae. No other macroor microfaunal elements were observed in this particular water hole, but a nearby water hole, presumably part of the same subterranean water system, harboured Typhlatya sp. (Decapoda Macrura) and Sesarma sp. (Decapoda Brachyura). Typhlatya is a wide-spread stygobiont element in the West Indies, probably of marine origin (cf. 
Stock, 1981), and Sesarma is a marine and mixohaline genus. In summary, most faunal elements in the water holes near the airport of Providenciales have distinct marine affinities.

The Amphipoda belong to a new genus, called Spelaeonicippe, closely related to the genus $\mathrm{Ni}$ cippe Bruzelius, 1859, a member of the family Pardaliscidae. This family is well-characterized by the mandible, lacking a distinct molar process; by the very small inner and outer plates of the maxillipeds; by the short coxal plates; and by the elongate, lanceolate rami of the third uropods (Barnard, 1969).

\section{BATHYMETRICAL DISTRIBUTION OF THE PARDAIISCIDAE}

The Pardaliscidae are predominantly bathyal/ abyssal/hadal, pelagic Amphipoda (Bousfield, 1978), and Birstein \& Vinogradov (1962: 249) consider them as "one of the basic abyssal families of gammarids". The genus Nicippe to which the present cave amphipods are most closely related, is not restricted to the deep sea. Most of its records are from the lower part of the continental shelf and the upper part of the continental slope (110600 m; cf. Metzger, 1875; Sars, 1893; Chevreux, 1900; Enequist, 1949; Gurjanova, 1951; Ledoyer, 1973, 1977), with exceptional deeper ones, down to $1393 \mathrm{~m}$ (cf. Stephensen, 1931). According to certain authors (Barnard, 1959; Karaman \& Schiecke, 1973) this genus penetrates also in waters of the upper part of the shelf, though always in the sublittoral (from $35 \mathrm{~m}$ down).

Although Bousfield (1978) states that the members of the Pardaliscidae are carnivorous, Enequist (1949) supposes that at least Nicippe might be a detritus feeder, and Wilkins \& Parzefall (1974) consider diatoms the primary food source of Spelaeonicippe buchi (as Nicippe).

Only one member of the family Pardaliscidae has been found outside the open sea in cave waters: Andres (1975) described a new species, under the name of Nicippe buchi, from a lava tunnel (the well-known Jameos del Agua) on the island of Lanzarote in the Canarian archipelago. As will be shown in the taxonomic part of the present paper, the Canarian cave species, though closely related to Nicippe, is still more close to the cave animals from Providenciales, and is therefore reckoned to the genus Spelaeonicippe. Certain differences in its appendages, in addition to the ocean-wide geographical gap between the caves of Providenciales and Lanzarote, justify in our opinion that the Canarian and West Indian populations are to be treated as separate species.

\section{THE HABITAT OF SPELAEONICIPPE}

Both localities from which Spelaeonicippe is known, Lanzarote and Providenciales, agree in at least three respects:

(1) The caves are of relatively young geological age. The Jameos del Agua on Lanzarote is part of a lava tube formed 3000-5000 years ago (Wilkins \& Parzefall, 1974). The extensive karst erosion, during which caves were formed by groundwater solution, on Providenciales developed during low sea-level stages (at -100 to $-120 \mathrm{~m}$ ) of the Pleistocene (Mather, 1975), thus sometime between 10,000 and $1,000,000$ years ago.

(2) The cave waters in Lanzarote and Providenciales are salty. The Lanzarote lava tube runs from the volcano la Corona to the coast where it is flooded by seawater. The blue holes and other karst features on Providenciales often extend below present sea level and are nowadays inundated by seawater, due to sea-level rises at the end of the ice ages, and - perhaps to a lesser extent - due to the general regional subsidence of the Bahamas platform.

In Lanzarote, the salinity in the cave fluctuates around $370 \%$ (corresponding with a chlorinity of some $20.4 \% \% 0$ ), which is slightly $(0-1 \% 00)$ inferior to that of the adjoining ocean (Wilkins \& Parzefall, 1974, table I). The water hole on Providenciales has a chlorinity that is distinctly lower than that of the surrounding ocean, viz. about $11.1 \%$ oo, but which is still very salty for inland groundwater. Apparently, fresh water mixes with salty groundwater of marine origin, a not uncommon situation in the Bahamian archipelago. (3) Spelaeonicippe has been found in both the West Indian and the Canarian locality in conditions where light could penetrate and not in total darkness. As to Lanzarote, Wilkins \& Par- 
zefall (1974) believe that this is not accidental, since the amphipods are supposed to feed on microscopic algae developing in the cave waters. For the West Indian locality, we are less certain about this point, because the totally dark parts of the "water hole" were not explored (so no information is available about presence or absence of Spelaeonicippe in those parts), and no diatom growth was observed in the entrance area of the cave.

ORIGIN OF THE FAUNA IN THE MARGINAL CAVES OF LANZAROTE AND PROVIDENCIALES

It can hardly be accidental that in the Jameos del Agua on Lanzarote, in addition to Spelaeonicippe buchi (a species which is undoubtedly related to the sublittoral/bathyal species Nicippe tumida Bruzelius, 1859), two other organisms with deepwater affinities occur: Munnidopsis polymorpha Koelbel, 1892 (Anomura, Galatheidae) and $M u$ cellicephala jameensis Hartmann-Schröder, 1974 (Polychaeta, Polynoidae).

We do not share Wilkins \& Parzefall's opinion (1974: 431) that the animals in the Jameos del Agua might be wide-spread in the deeper waters of the neighbouring Atlantic. Of course, the absence of eyes and of body pigmentation of the cavernicolous forms is analogous to similar reductions found in many deep-sea animals. On the other hand, the pardaliscid cave Amphipoda of Lanzarote differ in a number of morphological characters from the nearest marine relative. Furthermore, a second species of amphipod known from the same cave, a hadziid (see Andres, 1978) has no relatives at all in deeper waters. It must be stressed that both species of cave amphipods from Lanzarote have their closest relatives in fresh and brackish groundwaters of the West Indies. This makes it more likely that they descend from marine ancestors that during some phase of the evolutionary scenario became adapted to a life in the interstitia of coarse substrates (e.g. gravel). The adaptation to this kind of substrate might lie farther in the past for the exclusively benthic hadziid Gammaridae, than for the predominantly pelagic Pardaliscidae. Wilkins \& Parzefall (1974: 430) have observed that Spelaeonicippe buchi leaves the gravel on the cave bottom from time to time, to swim around freely, and to disappear again in the substrate after a while. The new species of Spelaeonicippe found in the West Indies shows a similar behaviour, but hadziid Gammaridae have never been observed swimming around freely in the water. The relatively recent origin (from marine ancestors) of the pardaliscid cave Amphipoda seems in good agreement with (1) the existence of close relatives in continental shelf and slope waters, and (2) their occurrence in geologically young caves, formed in pleistocene/ holocene times.

At any rate, if Spelaeonicippe or blind hadziid Gammaridae are to be discovered in the open sea, we suppose they will be shallow-water, meiofaunal elements in coarse substrates. It is from such elements, and not from abyssal ones, that the cave forms presumably evolved. In agreement with this view is the fact that the temperatures in the Lanzarote cave $\left(18.0-18.5^{\circ} \mathrm{C}\right)$ and in the Providenciales cave $\left(23.8^{\circ} \mathrm{C}\right)$ are closely similar to shallow-water temperatures in the neighbouring ocean, and not at all to bathyal/abyssal temperatures of $10-4^{\circ} \mathrm{C}$ in the neighbouring ocean.

\section{TAXONOMIC PART}

Spelaeonicippe n. gen.

Family Pardaliscidae (Amphipoda). Resembling the genus Nicippe in the general shape of the telson, of the mouthparts, and of the large, oval propodus in the gnathopods 1 and 2. Differs from Nicippe in the characters enumerated in table I. Type-species: $S$. provo n. sp.

Other species: S. buchi (Andres, 1975) (as Nicippe).

Distribution: Cave waters on Providenciales (Caicos Islands) and Lanzarote (Canary Islands). Derivatio nominis: From $\sigma \pi \dot{\eta} \lambda \alpha \iota \circ$ (Greek, cave) and Nicippe (a generic name in pardaliscid Amphipoda, based on Greek mythology and named after the daughter of Pelops). Gender feminine. Remarks: We consider in particular the non-transformed first male antenna as a diagnostic character of the new genus. 
TABLE I

Salient differences between the genera Nicippe Bruzelius, 1859, and Spelaeonicippe n. gen.

\begin{tabular}{|c|c|}
\hline Nicippe & Spelaeonicippe \\
\hline $\begin{array}{l}\text { 1. Lateral head lobes large, acutely produced } \\
\text { 2. A1 }>A 2 * * \text { ) } \\
\text { 3. Segments of accessory flagellum of } A 1 \delta \text { transformed } \\
\text { 4. Flagellum segment } 1 \text { of } A 1 \text { o elongated, with extra } \\
\text { setation } \\
\text { 5. Second and third segment of } \mathrm{Md} \text { palp with dense } \\
\text { setation } \\
\text { 6. Distal palp segment of } \mathrm{M} \times 1 \text { clavate (with strong distal } \\
\text { dilatation); armature restricted to terminal margin } \\
\text { 7. Outer lobe of } \mathrm{Mx1} \text { less wide than } 2 \mathrm{nd} \text { palp segment } \\
\text { 8. Outer lobe of } \mathrm{Mx} 1 \text { reaches to } 75 \% \text { of the length of } \\
\text { the palp } \\
\text { 9. Segments } 2,3 \text { and claw of } \mathrm{Mxp} \text { palp slender } \\
\text { 10. Outer lobe of } \mathrm{Mxp} \text { setiferous } \\
\text { 11. Outer lobe of } \mathrm{Mxp} \text { reaches to the end of the inner } \\
\text { margin of palp segment } 1 \\
\text { 12. Merus of } \mathrm{P5} \text { setiferous } \\
\text { 13. Urosomite } 1 \text { with dorsal teeth }\end{array}$ & $\begin{array}{l}\text { Inconspicuous, rounded } \\
\text { A1 }<\text { A2 } \\
\text { Normal } \\
\text { Short, without special setation } \\
\text { With sparse setation } \\
\text { Not dilated; armature on terminal and medial margins } \\
\text { Wider than 2nd palp segment } \\
\text { To } 33 \% \\
\text { Plump } \\
\text { Spiniferous } \\
\text { Does not reach the end } \\
\text { Spiniferous } \\
\text { Smooth }\end{array}$ \\
\hline
\end{tabular}

**) Sars, 1893, pl. 145, illustrates a male of Nicippe tumida Bruzelius in which A1 is slightly shorter than A2, but Karaman \& Schiecke (1973: 166) consider this an exceptional case.

\section{Spelaeonicippe provo n. sp.}

Materia l. - One $\$$ (holotype), one of (allotype), eight paratypes. Amsterdam Expeditions to the West Indian Islands, sta. 79-151. Providenciales (Caicos Islands): nameless "water hole" N.W. of the airfield (estimated position $21^{\circ} 46^{\prime} 50^{\prime \prime} \mathrm{N}$ $\left.72^{\circ} 16^{\prime} 30^{\prime \prime} \mathrm{W}\right)$; stones, silt; semi-dark; water depth over $1 \mathrm{~m}$; water temperature $23.8^{\circ} \mathrm{C}$; chlorinity $11,108 \mathrm{mg} / \mathrm{l} ; 16 \mathrm{No}$ vember 1979. Zoölogisch Museum Amsterdam coll. no. ZMA Amph. 107.495.

Des c r i pt i o n. - Body length of adult specimens 3-4 mm; body unpigmented (intestine pink); no eye pigment. Urosomites 2 and 3 with 1 or 2 minute dorsal setules; dorsum otherwise smooth. Coxal plates low. Lateral head lobes inconspicuous, rounded; no rostrum. Epimeral plates with rounded posterior corners (fig. 1a).

First antenna (fig. $1 \mathrm{~b}$ ) reaching to the end of the pedunculus of the second antenna. Pedunculus segments heavy and short. Accessory flagellum 3-segmented, almost as long as second pedunculus segment. Flagellum 17- to 18-segmented; aesthetasks on segment 1 ( 6 long aesthetasks), 3 and 4 (each 2 long aesthetasks), 6, 7, 8, 9 and 10 (each 1 short aesthetask).

Second antenna (fig. 1c): gland cone short, conical. Pedunculus segments 4 and 5 elongate; ventrally armed with a row of spinules, dorsally with groups of short setae. No calceoli. Flagellum 16- to 17-segmented.

Labrum (fig. 1d) bell-shaped.

Masticatory part of mandible asymmetrical (figs. 1e, 1f): left mandible with, right mandible without lacinia mobilis. Pars molaris reduced; cutting edge long, almost toothless; a row of 8-11 spines is present between the cutting edge and the implantation of the palp. Palp slender; segment 1 unarmed; segment 2 with 7 or 8 ventral setae; third segment narrower than the second, with 2 terminal and 2 subterminal setae only.

Labium (fig. 1g) deeply cleft, without inner lobes.

First maxilla: left (fig. 2b) and right (fig. 2a) appendages almost symmetrical. Inner lobe triangular, with 1 apical seta; outer lobe squarish, armed with 7 strong distal spines. Palp 2-segmented; distal segment ovate, not dilated distally; medial and distal margins with some 13 short spines.

Second maxilla (fig. 2c) consisting of two very slender, digitiform, lobes. Outer lobe with 3 distal setae; inner lobe with 8 or 9 medial setae.

Maxilliped (fig. 1h): inner lobe small, ovate, 


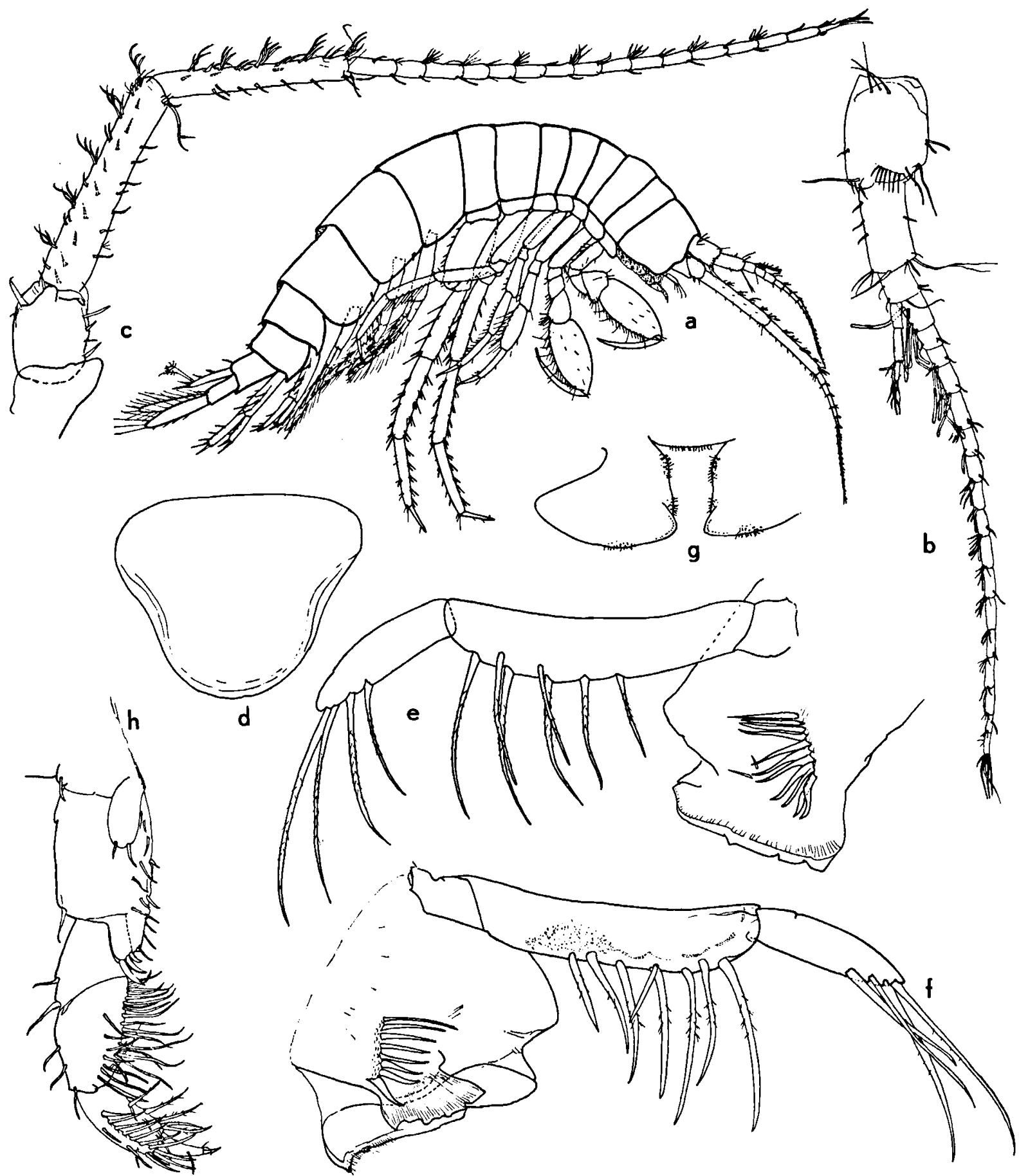

Fig. 1. Spelaeonicippe provo n. gen., n. sp., $\&$ paratype: a, entire animal from the right (real size abt. $4 \mathrm{~mm}$ ); b, first antenna (scale A); c, second antenna (A); d, labrum (B); e, right mandible (B); f, left mandible (B); g, labium (B); h, maxilliped (C). Scales see fig. 4. 


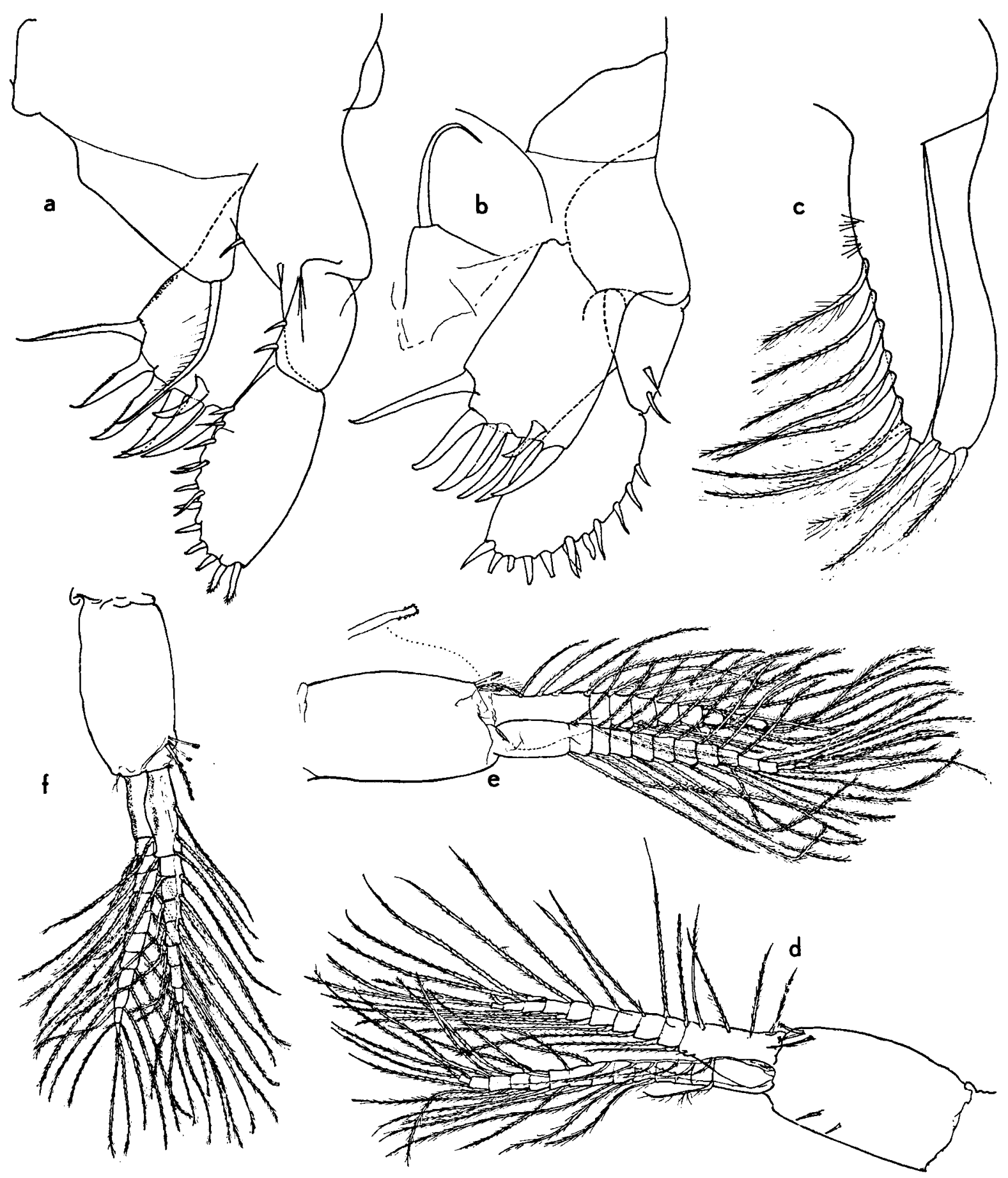

Fig. 2. Spelaeonicippe provo n. gen., n. sp., \& paratype: a, right first maxilla (scale B); b, left first maxilla (B); c, second maxilla (B); d, first pleopod (A); e, second pleopod (A); $f$, third pleopod (A). Scales see fig. 4. 
with 2 distal setae. Outer lobe very short, not reaching the distal end of the first segment of the inner margin of the palp, armed with 3 distal spines and several short medial setae. Palp segments short and robust.

First gnathopod (fig. 3a): Coxal plate with a rounded anterior projection. Carpus triangular. Propodus large, ovate. No palmar angle marked; the entire posterior edge of the propodus forms the palmar margin. This margin (fig. $3 \mathrm{~b}$ ) is densely packed with some 40 shorter setae (the proximal margin of which bears many cilia, the distal margin fewer cilia) and 5 longer setae (the proximal margin of which bears few cilia, the distal margin many). Claw long, curved; one very short setule on its outer margin.

Second gnathopod (fig. 3c) slightly larger than the first, but otherwise very similar.

Oöstegites on gnathopod 2 and pereiopods 3 to 5; linear, armed with long setae. Coxal gills with an indistinct basal stalk, ovate to sausage-shaped, decreasing in size from anterior to posterior, present on gnathopod 2 and pereiopods 3 to 7.

Third pereiopod (fig. 3d) with modified carpus: this segment is slightly swollen and armed with numerous long, plumose setae on its posterior margin. The propodus on the contrary is practically unarmed, except for some short plumose elements on the distal end of its posterior margin. The claw is extremely elongate.

Fourth pereiopod (fig. 4a) with trapezoidal coxal plate, without posterior excavation. Carpus not swollen and armed with a limited number of short plumose setae only. Propodus with numerous short plumose setae on the entire posterior margin. Claw as in the third pereiopod.

Fifth pereiopod (fig. 3e) slightly longer than the fourth. Basis almost linear in shape; posterodistal corner produced into a strongly overhanging lobe. Merus armed with a few short spines only. Carpus not swollen but armed with a row of long setae and some spines along its anterior margin. Anterior margin of propodus with similar armature.

Sixth pereiopod (fig. $4 \mathrm{~b}$ ) much longer than the fifth. Basis less linear than in the fifth pereiopod, with a very strongly produced and overhanging posterodistal lobe. Seventh pereiopod (fig. 4c) as long as the sixth; basis much wider than that of the sixth, but likewise with a strongly overhanging lobe. Both sixth and seventh pereiopod armed with spines only.

Pleopods 1 to 3 (figs. 2d, e, f) similar in morphology; pleopod 3 slightly shorter than the others. All pleopods are biramous and the rami are untransformed in both sexes. Two retinacula on each pleopod; the retinacula are exceptionally long; the extreme distal part bears rake-like teeth (fig. 2e, detail).

Uropods 1 (fig. 4d) and 2 (fig. 4e) not much different in length; both with short exopodite (0.6-0.7 times as long as the endopodite).

Third uropod (fig. 4f) equiramous, both rami 1-segmented, rather wide, lanceolate to foliaceous. Outer margin of exopodite armed with 3 or 4 spines. Outer margin of endopodite with a limited number of plumose setae. Inner margin of exoand endopodite with numerous long, plumose setae.

Telson (fig. 4g) deeply cleft; lateral margin of each slender half with 2 spines; distal part with 2 plumose (sensory) setae and 2 spines.

No secondary sexual differences have been observed in the appendages of males and females.

D is t in ction. - S. provo n. sp. is very similar to S. buchi (Andres, 1975) from Lanzarote. The following differences exist between the two species:

(1) Body length $3-4 \mathrm{~mm}$ in $S$. provo (versus 7-10 mm in $S$. buchi); (2) segment 1 of antenna 1 only slightly longer than wide in $S$. provo (elongate in S. buchi); (3) segment 2 of $A 1$ about $4 / 5$ of the length of segment 1 in $S$. provo (about $1 / 2$ the length in $S$. buchi); (4) molar process of mandible replaced by 8 to 11 spines in S. provo (2 to 3 in S. buchi); (5) 2nd mandible palp segment with 7 to 8 ventral setae in $S$. provo ( 1 in $S$. buchi); (6) 2nd palp segment of maxilla 1 with at least 10 spines in $S$. provo $(5$ in $S$. buchi); (7) posterior margin of basis of gnathopods 1 and 2 with several long setae in $S$. provo (unarmed in $S$. buchi); (8) propodus of pereiopod 4 with setae on the posterior margin in $S$. provo (spinules only in S. buchi); (9) overhanging posterodistal lobe on the basis of pereio- 


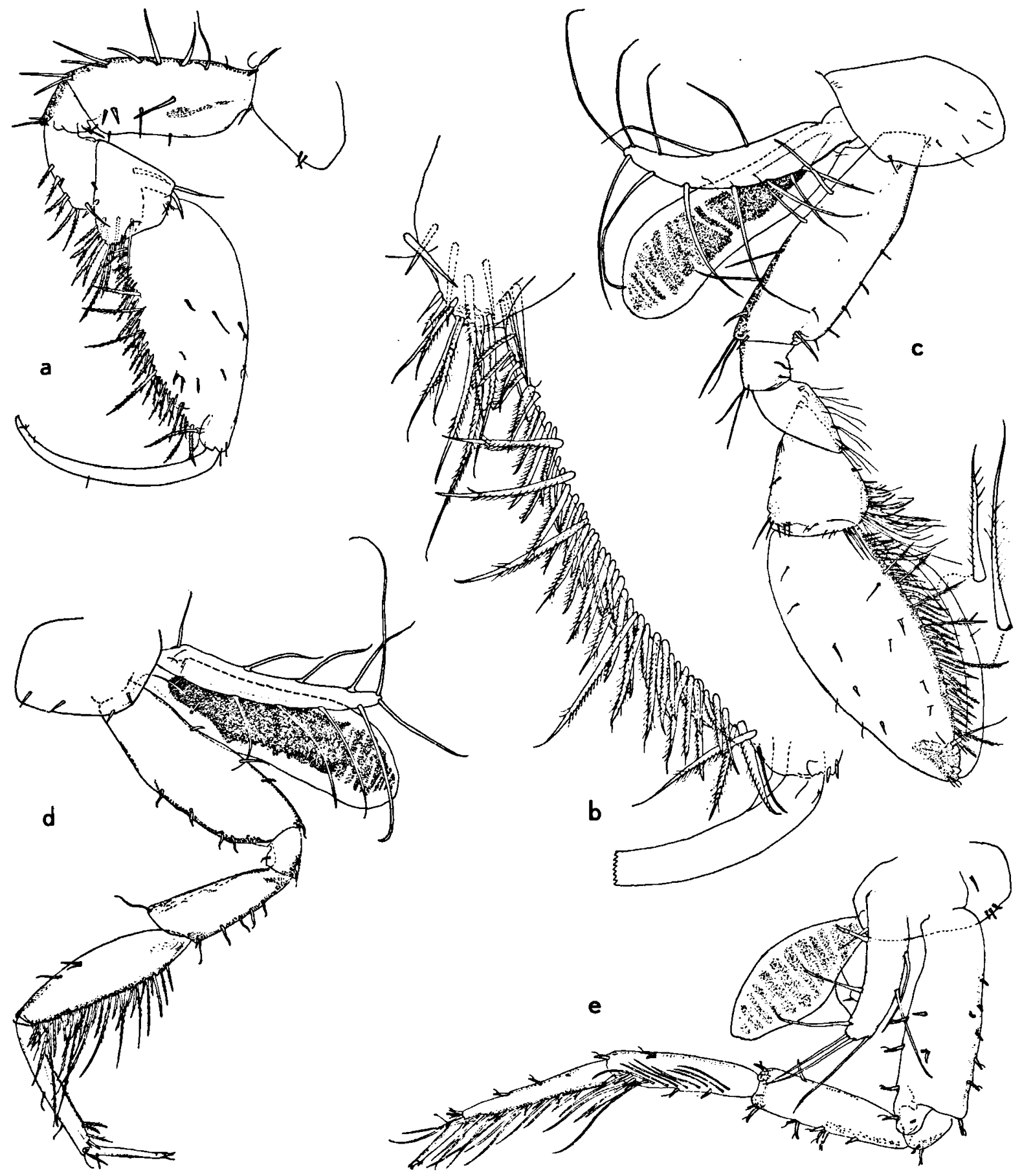

Fig. 3. Spelaconicippe provo n. gen., n. sp., $ᄋ$ paratype: a, first gnathopod (scale A); b, palmar margin of propodus of first gnathopod (D); c, second gnathopod (A); d, third pereiopod (A); e, fifth pereiopod (A). Scales see fig. 4. 


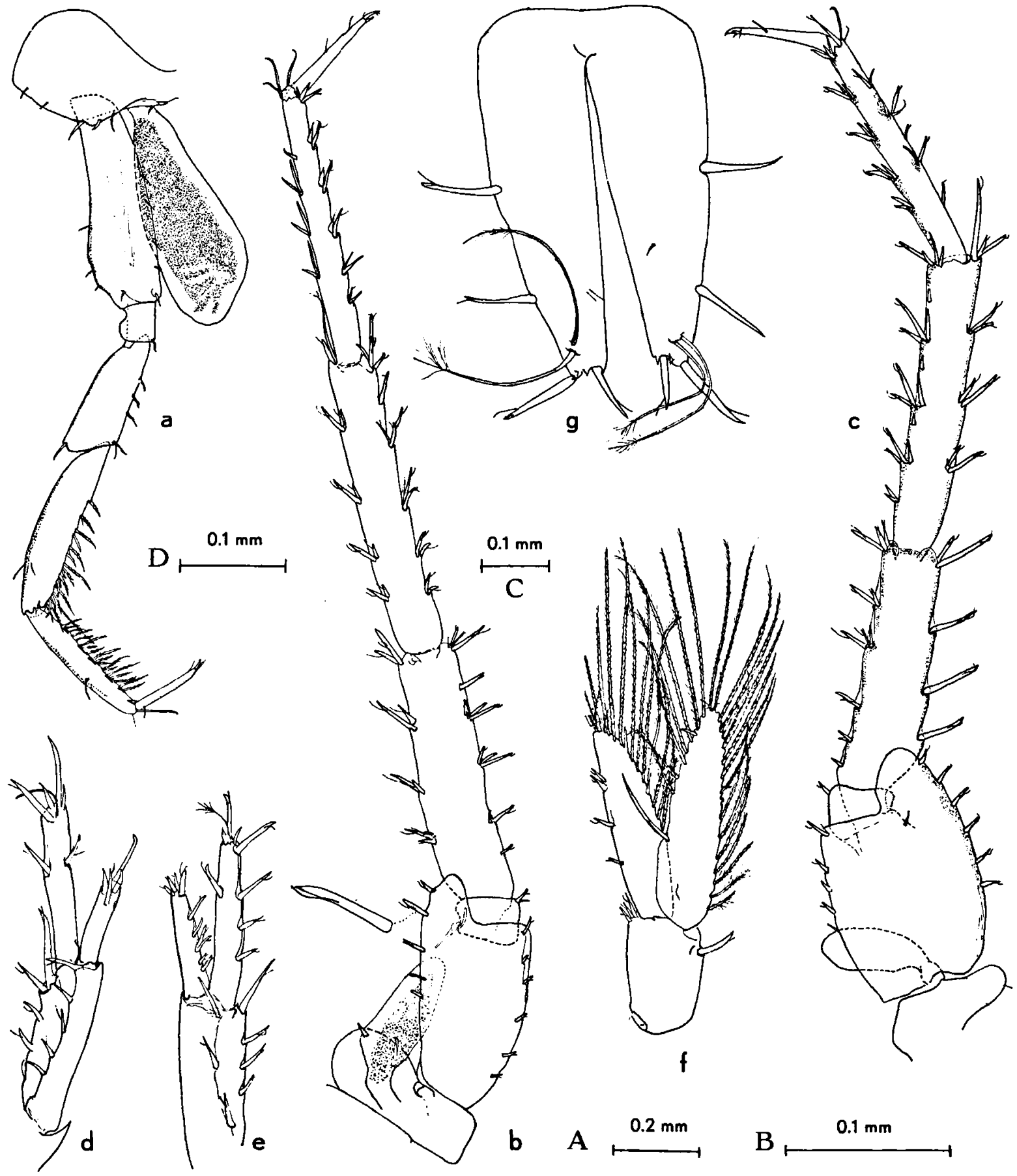

Fig. 4. Spelaeonicippe provo n. gen., n. sp., a-f, $\$$ paratype; g, $\delta$ allotype: a, fourth pereiopod (scale A); b, sixth pereiopod (A); c, seventh pereiopod (A); d, first uropod (A); e, second uropod (A); $f$, third uropod (A); $g$, telson (C). 
pods 5 to 7 very strongly developed in $S$. provo (moderately developed in $S$. bucbi); (10) outer margin of endopodite of uropod 3 with long plumose setae in $S$. provo (with spines only in $S$. bucbi); (11) telson with 2 lateral spines in S. provo (1 lateral spine in S. buchi); (12) sensory setae implanted near the tip of the telson lobes in $S$. provo (slightly over the middle in S. buchi).

Derivatio nom in is. - The specific name, provo, is the popular name for the type-locality, the island of Providenciales.

\section{ACKNOWLEDGEMENTS}

The fieldwork on which the present paper is based has been supported by grants from the Netherlands Foundation for the Advancement of Tropical Research (WOTRO), The Hague; The Treub Maatschappij, Utrecht; The BeijerinckPopping Fonds, Amsterdam; and the Fonds Landbouwhogeschool, Wageningen.

Dr. Steven Weinberg is thanked for assistance during the 1979 sampling program in the Bahamas.

H.M. Embassy of The Netherlands in Kingston (Jamaica) provided logistic support, which is gratefully acknowledged.

We are also indebted to Dr. H. E. Coomans (Institute of Taxonomic Zoology, University of Amsterdam) for identifying the Gastropoda found along with the Amphipoda at the type-locality.

\section{REFERENCES}

Andres, H. G., 1975. Nicippe buchi n. sp., ein Pardaliscide aus einem Lavatunnel auf Lanzarote (Amphipoda, Crustacea). Mitt. Hamburg. zool. Mus. Inst., 72: 91-95.

- 1978 . Liagoceradocus acutus sp. n., ein Gammaride aus der Jameos del Agua auf Lanzarote (Amphipoda, Crustacea). Mitt. Hamburg. zool. Mus. Inst., 75: 249-253.

BARNARD, J. L., 1959. The common pardaliscid Amphipoda of southern California, with a revision of the family. Pacific Natural., 1 (12): 36-43.

- 1969. The families and genera of marine gammaridean Amphipoda. Bull. U.S. natn. Mus., 271: i-vi, 1-535.

Birstein, J. A. \& M. E. Vinogradov, 1962. Notes on the family Pardaliscidae (Amphipoda) with the description of a new genus. Crustaceana, 3 (4): 249-258.
Bousfiet.d, E. L., 1978. A revised classification and phylogeny of amphipod crustaceans. Trans. roy. Soc. Canada, (4) 16: 343-389.

Chevreux, E., 1900. Amphipodes provenant des campagnes de l"«Hirondelle». Résult. Camp. scient. Prince Albert I, 16: i-iv, 1-196, pls. I-XVIII.

ENEQUisT, P., 1949. Studies on the soft-bottom amphipods of the Skagerak. Zool. Bidr. Uppsala, 28: 297-492, 1 chart.

GuRJANOvA, E., 1951. Bokoplavy morej SSSR i sopredel'nykh vod (Amphipoda-Gammaridea). Opred. Faune SSSR (Akad. Nauk SSSR), 41: 1-1029.

Holrhuis, L. B., 1973. Caridean shrimps found in landlocked saltwater pools at four Indo-West Pacific local. ities (Sinai Peninsula, Funafuti Atoll, Maui and Hawaii Islands), with the description of one new genus and four new species. Zool. Verhand. Leiden, 128: 1-48.

Karaman, G. S. \& U. SCHIECKE, 1973. Some interesting Amphipoda of the Pardaliscidae family (Amphipoda, Gammaridea) of the Adriatic and Mediterranean Seas. Memorie Mus. civ. Stor. nat. Verona, 20: 149-168.

LEDOYER, M., 1973. Amphipodes gammariens nouveaux ou peu connus de la région de Marseille. Téthys, 4 (4): 881.898.

—_, 1977. Contribution à l'étude de l'écologie de la faune vagile profonde de la Méditerranée nord occidentale, I. Les Gammariens (Crustacea, Amphipoda). Boll. Mus. civ. Stor. nat. Verona, 4: 321-421.

Mather, J. D., 1975. Turks and Caicos Islands. In: R. W. FAIRBRIDGE ed., The encyclopedia of world regional geology, 1. Western hemisphere: 500-501 (Dowden, Hutchinson \& Ross, Stroudsburg, Pa., U.S.A.).

MEtZGER, A., 1875. Zoologische Ergebnisse der Nordseefahrt, 10. Crustaceen aus den Ordnungen Edriophthalmata und Podophthalmata. Jber. Comm. wiss. Untersuch. dt. Meere, 2/3: 277-310, pl. VI.

RiedL, R. \& B. OzRETIČ, 1969. Hydrobiology of marginal caves, I. General problems and introduction. Int. Revue ges. Hydrobiol., 54 (5): 661-683.

SARS, G. O,, 1893. An account of the Crustacea of Norway, 1 (Amphipoda) (18): 389-412, pls. 137-144 (Cammermeyer, Christiania).

Stephensen, K., 1931. Crustacea Malacostraca, 7 (Amphipoda, 3). Danish Ingolf Exped., 3 (11): 178-290.

Sтоск, J. H., 1981. L'origine géologique des îles des Indes Occidentales en relation avec la dispersion de quelques Malacostracés stygobiontes. Géobios (Lyon), 14 (2): 219-227.

Wilkins, H. \& J. Parzefall, 1974. Die Oekologie der Jameos del Aqua (Lanzarote). Zur Entwicklung limnischer Höhlentiere aus marinen Vorfahren. Annls. Spéléol., 29 (3): 419-434. 